\title{
EFFECT OF PRE-DRYING HANDLING ON QUALITY OF FINAL DRIED BOMBAY DUCK (HARPODON NEHERIUS)
}

Krishna Prasad Nooralabettu

Department of Biotechnology, Pallikere Abdullah College of Engineering, Nadupadavu, Mangalore, Karnataka, India, Pin-574153., lodhariad1@hotmail.com

Follow this and additional works at: https://jmstt.ntou.edu.tw/journal

Part of the Life Sciences Commons

\section{Recommended Citation}

Nooralabettu, Krishna Prasad (2011) "EFFECT OF PRE-DRYING HANDLING ON QUALITY OF FINAL DRIED BOMBAY DUCK (HARPODON NEHERIUS)," Journal of Marine Science and Technology. Vol. 19: Iss. 4, Article 1.

DOI: $10.51400 / 2709-6998.2173$

Available at: https://jmstt.ntou.edu.tw/journal/vol19/iss4/1

This Research Article is brought to you for free and open access by Journal of Marine Science and Technology. It has been accepted for inclusion in Journal of Marine Science and Technology by an authorized editor of Journal of Marine Science and Technology. 


\title{
EFFECT OF PRE-DRYING HANDLING ON QUALITY OF FINAL DRIED BOMBAY DUCK (HARPODON NEHERIUS)
}

\author{
Krishna Prasad Nooralabettu*
}

Key words: Bombay duck, drying, salting, non-protein nitrogenous substances, free fatty acids, peroxide value.

\begin{abstract}
Proliferation of spoilage microorganisms during preprocessing delay, with associated deteriorative changes in non-protein nitrogenous substances and lipids, and its impact of the sensory characteristics of the final dried products were studied. Bombay duck was judged as unfit for human consumption beyond $8 \mathrm{hrs}$ of exposure at $28^{\circ} \mathrm{C}$. However, chilling the fish to $0^{\circ} \mathrm{C}$ or salting the fish after gutting at $28^{\circ} \mathrm{C}$ or drying at $45^{\circ} \mathrm{C}$ without delay effectively reduced the proliferation of spoilage microorganisms, and associated biochemical and sensory characteristics during drying. Higher levels of proteolytic and lipolytic bacterial load, free fatty acids, trimethylamine and total volatile bases due to predrying exposure at $28^{\circ} \mathrm{C}$ without salt or $10 \%$ salt solution resulted in dried fish with least sensorial characteristics. Predrying exposure at $0^{\circ} \mathrm{C}$ did not had any effect on the development of peroxides compared to $28^{\circ} \mathrm{C}$, however exposure to saturated salt solution or dry salt enhanced the development of peroxides. Dressed Bombay duck, treated with $20 \%$ salt solution for 16 hours and artificially dried at $45^{\circ} \mathrm{C}$ was judged superior by sensory panel.
\end{abstract}

\section{INTRODUCTION}

Harpodon neherius, is a single species fishery of high magnitude along Gujarat and Maharashtra coast. It is popularly known as Bombay duck, and one of the largely produced and relished dried fish in the coastal and some interior parts of India. Due to very high moisture content of $90.98 \%$, it is unsuitable to use either in fresh form or in frozen form, and almost entire catch of the Bombay duck is consumed in unsalted and sundried form [27]. Abundant catches of Bombay duck is transported from the fishing ground to the landing

Paper submitted 04/22/09; revised 10/20/09, 01/26/10; accepted 03/18/10. Author for correspondence: Krishna Prasad Nooralabettu (e-mail: lodhariad1@ hotmail.com).

*Department of Biotechnology, Pallikere Abdullah College of Engineering, Nadupadavu, Mangalore, Karnataka, India, Pin- 574153. center without icing and depending on the distance from the shore to the fishing ground, it takes more than four hours to reach the shore. Heaps of the landed Bombay duck during odd hours during peak seasons has to wait for considerable length of time of their disposal, resulting in inevitable deterioration in quality. Fresh fish stored at ambient temperature becomes unsuitable for human consumption within 12 hours [28].

Such raw materials are dried on the shore without salting in sun shine that may takes more than three days depending on the weather conditions. Initial freshness of raw material affects the end product [27]. Main reasons for the availability of most of the low quality dried fish along Kerala, Tamilnadu and Maharashtra coast is due to the effect of the nature of the raw material, pre-drying delay, unhygienic handling, unpredictable weather condition, improper salting practices and unprotected storage on the quality of the dried fish and its keeping quality $[3,11,19]$.

Non-protein nitrogenous compounds and lipids are involved in post mortem reactions in the flesh of fish. Accumulation of non protein nitrogenous substance such as trimethylamine, total volatile bases and free amino acids due to microbial and indigenous enzymes in the fish flesh results in unacceptability of the product for human consumption $[5,18$, $30,32,33]$. Deteriorative changes in lipids due to its susceptibility for oxidation or enzymatic reaction results in the formation of components that are associated with undesirable secondary reactions of the dried fish product $[10,12,13,26$, 31]. Hence, changes in non protein nitrogenous substances and deteriorative changes in lipids in fish muscle serves as a measure of freshness or staleness of seafood, and helps in making a strategy to improve the existing traditional processing methods to produce the product of consumer acceptability.

Spoilage rate can be reduced to greater extent by chilling as the spoilage retarding effect is especially high close to freezing point of fish flesh, and on the other hand rate of spoilage and period of drying can be reduced, and sensory properties of the products can be improved by salting. Even after being an important fishery of Maharashtra and Gujarat coast not much attempt has been made to improve the traditional method of processing. Pre-drying spoilage contribute considerable nutritional loss in food chain and drying technique is often 
considered to produce durable product of energy saving one compared to frozen products and little or no additional energy is required, and hence considerable scope exists for improving quality of dried fish produced in India to feed the poor people by improving the processing techniques. This is an attempt to study the impact of deteriorative changes taking place during pre-drying holding on the keeping quality of the final dried product, and we have made an effort to reduce the rate of deterioration in Bombay duck by chilling or salting after gutting, and artificial drying.

\section{MATERIALS AND METHODS}

\section{Fish Samples}

The Fresh Bombay Duck (FBD) samples were transported in an insulated container after adequately icing them in the proportion of 1:1 fish to ice, to the laboratory of Central Institute of Fisheries Education (ICAR). The time lapsed between catching at the fishing ground and processing may not exceed over four to six hours and temperature recorded during the catching and the processing did not exceed $4^{\circ} \mathrm{C}$. The FBD samples belonging to size group of 21 to $23 \mathrm{~cm}$ long; weighing around 80 to $85 \mathrm{~g}$ were sorted out on a sanitized stainless steel working table were washed using chilled running water system maintained between $2-4^{\circ} \mathrm{C}$. FBD procured in this manner was used in two lots for studying the effect of post harvest delay on the quality of the final dried product.

\section{Effect of Preprocessing Delay on the Quality of the Freshly Caught Bombay Duck}

To study the effect of preprocessing delay on the quality of the raw material, first lot freshly caught fish was divided in to four sub-lots, and the first three sub-lots were exposed to the temperature of $28^{\circ} \mathrm{C}$ for 4,8 , and 12 hours, and the last sub-lot was exposed to the temperature of $0^{\circ} \mathrm{C}$ for 12 hours in thermostatically controlled cooling incubator (Rotek, Cochin) in the polythene pouches (US-28C/4H, US-28C/8H, US-28C/12H and US-0C/12H respectively). Samples were drawn from each sub-lot at regular intervals of incubation period for further analysis.

\section{Effect of Gutting and Salting on the Deteriorative Changes of Bombay Duck}

Combined effect of gutting and salting on pre-drying spoilage was studied on second lot of FBD after gutting by slit opening the belly without removing the head, fins or tails under sanitary conditions, washing under chilled running water system. Dressed Bombay duck (DBD) produced in this manner was divided in to four sub-lots, and the first three sub-lots were treated with 10, 20 and 36\% (Saturated) salt solution in the ratio of 1:1.5 salt solution to fish proportion, and the fourth sub-lot was treated with dry salt in the ratio of 1:6 salt to fish proportion as per Bureau of Indian Standards specifications $[16,17]$ for 16 hours (SA10-DBD, SA20-DBD, SA36-DBD and SADS-DBD, respectively). The common salt, having around $99 \%$ sodium chloride obtained locally from market with the size of 3-5 mm of coarse salt in $2 / 3$ parts and the size of $1-0.5 \mathrm{~mm}$ fine salt in $1 / 3$ parts were used. Salting was done as per the method explained by the Bureau of Indian Standards specifications [15-17]. Samples were drawn from each sub-lot at regular intervals of time for further analysis. The visceral organs were pulled out after split opening the belly. Washed and dressed Bombay duck is washed in 3.5\% salt solutions, so as to remove blood, slimes, dirt etc. The material was drained prior to drying.

\section{Artificial Drying of the Samples with Different Pre-drying Conditions}

Samples held at 28 or $0^{\circ} \mathrm{C}$ with or without salts (DBD, US-28C/4H, US-28C/8H, US-28C/12H, US-0C/12H, SA10DBD, SA20-DBD, SA36-DBD and SADS-DBD) were dried in Torry kiln (Torry Research Station, UK) at the temperature of $45^{\circ} \mathrm{C}$ with air velocity of 1.003 meter/second and relative humidity of $60 \pm 2 \%$. All the samples were hung on one meter long iron rods after interlocking the jaws which were mounted on wooden frames of the trolley and were loaded in the drying chamber of the kiln with proper labeling. The temperature, air velocity and relative humidity was monitored regularly, recorded at regular intervals of time and maintained at constant rate. Samples were drawn from artificial dried samples at regular intervals of time for analysis.

\section{Proximate Analysis}

Samples drawn and analyzed at different intervals of processsing were performed in quadruplicates. The wet fish samples were blended in a homogenizer (Rotec, Cochin) at 3,000 rpm for 10 minutes and dried fish samples were powdered in a Waring blender (Philips India, Bombay) at 22,000 rpm for 10 minutes. Moisture content of the samples were estimated as per FAO [9] and expressed as percentage of moisture. Salt content of samples were estimated as per FAO [8] and expressed as percentage of salt. The total lipid in the fish was extracted using chloroform methanol phase separation and peroxide value (POV) of the samples were estimated by the method described by Lima and others [24], and expressed as millimoles of oxygen $/ \mathrm{kg}$ of fat. Free fatty acids (FFA) of the sample were estimated by the method described by IS: 5734 [15] and is expressed as percentage of oleic acid on lipid basis. Trichloro acetic acid extract was prepared as per FAO [9] and used for measuring nonprotein nitrogenous substances (NPNs) like trimethylamine nitrogen (TMAN), total volatile bases nitrogen (TVBN) and alpha amino nitrogen (AAN). TMAN and TVBN content of the sample was determined by the micro diffusion method as described by Martin [25] and the values were expressed as $\mathrm{mg} / 100 \mathrm{~g}$ of fish muscle. The AAN in the samples were estimated by the method described by Pope and Stevens [29] and value is expressed as $\mathrm{mg} / 100 \mathrm{~g}$ fish muscle.

\section{Microbiological Methods}

Glassware and prepared media were sterilized using moist 
heat at $121^{\circ} \mathrm{C}$ for 15 minutes. Petri dishes, homogenizers, pipettes were sterilized using dry heat at $180^{\circ} \mathrm{C}$ for 1 hour. skimmed milk $10 \%$, trybutyrin solution $10 \%$ were sterilized by tendylisation method, where solution was free steamed for 1 hour on first day and for 30 minutes on the next 2 successive days. Mesophilic bacterial count (MBC) was determined as per APHA [2] method. MBC was enumerated and expressed as mesophiles per gram of sample on dry weight basis. Proteolytic bacterial count (PBC) was determined using the method of Leo [23]. Proteolytic positive bacterial colony forms clear zone around the colony and was expressed as number of proteolytic bacteria per gram of sample on dry weight basis. Lipolytic bacterial count (LBC) was determined by the method explained by Collines [4] using Trybutyrin agar. Hydrolysis of trybutyrin results in clearing of medium and formation of a clear zone around the colony, which was enumerated and expressed as lipolytic count per gram of sample on dry weight basis. Total mould count (TMC) was determined according to the method described by Leo [23], which was enumerated and expressed as total mould count per gram of sample on dry weight basis.

\section{Sensory Evaluation}

Sensory attributes like appearance, colour, odor, texture, and flavour were conducted using a ten member panel of trained professionals. Samples were labeled in such a way that the panelist will not be able to identify them and were placed in separate booths. The panelists were provided with clean water to rinse their mouth after tasting each sample. The samples were evaluated using a nine point hedonic scale basis $(9=$ like extremely, $8=$ like very much, $7=$ like moderately, $6=$ like slightly, $5=$ neither like nor dislike, $4=$ dislike slightly, $3=$ dislike moderately, $2=$ dislike very much and $1=$ dislike extremely) [22].

\section{Chemicals}

All the chemicals used were of analytical grade and were obtained from Merck Limited (Mumbai, India).

\section{Statistical Analysis}

A completely randomized design was performed using quadruplicate samples through the study. One- and two-way ANOVA was performed using Statographics 2.1 (STSC Inc., Rock vile, MD). The difference in means was analyzed using a Turkey HSD test $(p<0.05)$.

\section{RESULTS AND DISCUSSIONS}

\section{Effect of Pre-drying Delay on the Quality of the Freshly Caught Bombay Duck}

When FBD samples were held at $28^{\circ} \mathrm{C}$ for 12 hours (US$28 \mathrm{C} / 12 \mathrm{H}), \mathrm{MBC}$ was increased by $538.46 \pm 0.25$ folds, but as the temperature of the storage of the samples reduced to $0{ }^{\circ} \mathrm{C}$ (US-0C/12H) the increase of $\mathrm{MBC}$ was reduced drastically to $7.89 \pm 0.025$ folds. US-28C/12H registered higher $(p<0.05)$
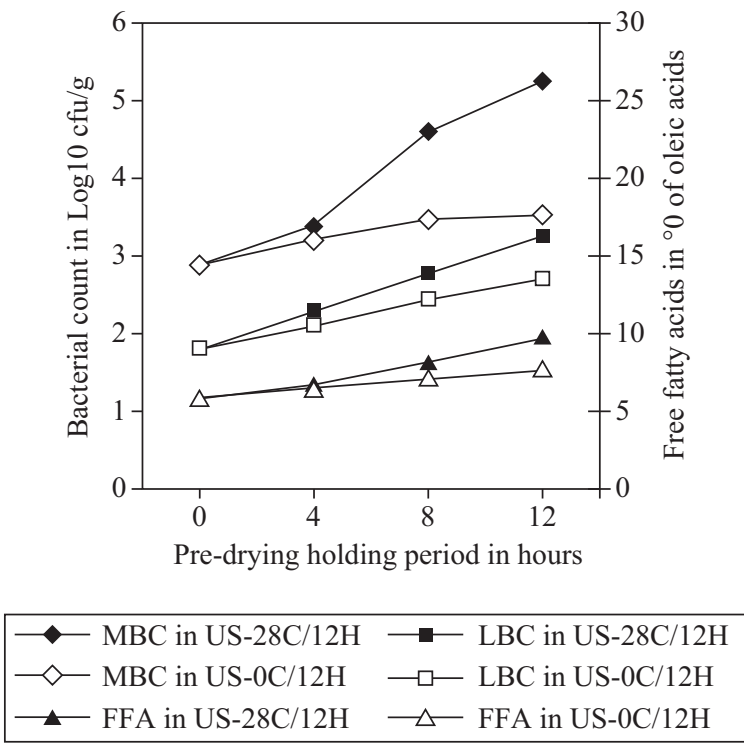

Fig. 1. Changes in $\mathrm{MBC}, \mathrm{LBC}$ and FFA in FBD during storage at $0^{\circ} \mathrm{C}$ or $28^{\circ} \mathrm{C}$.

levels of MBC compared to US-0C/12H samples, all along the storage period. $\mathrm{PBC}$ increased by $79.00 \pm 0.022$ folds at $28^{\circ} \mathrm{C}$, but only by $15.53 \pm 0.021$ folds at $0^{\circ} \mathrm{C}$. Similarly during 12 hours of holding, LBC increased by $81.5 \pm 0.025$ folds at $28^{\circ} \mathrm{C}$, but only by $17.20 \pm 0.023$ folds at $0^{\circ} \mathrm{C}$. On the other hand, FFA in US-28C/12H samples increased by $1.60 \pm 0.019$ folds in 12 hours, but in US-0C/12H samples the increase was only by $1.30 \pm 0.02$ folds (Fig. 1).

Reduction in the release of FFA in chilled fish (US-0C/ $12 \mathrm{H}$ ) compared to samples stored at ambient temperature (US$28 \mathrm{C} / 12 \mathrm{H})$ may be due to decreased lipolyitc activity close to freezing point of fish flesh [20], as at ambient temperature autolytic or bacterial lipase catalyze the release of FFA from glycerides and phospholipids [12]. Accumulation of FFA in fish flesh is undesirable due to secondary reactions leading to quality deterioration [1].

Similarly, when FBD samples were stored at $28^{\circ} \mathrm{C}$, TMAN, TVBN and AAN increased by $4.44 \pm 0.021,5.53 \pm 0.022$ and $2.40 \pm 0.02$ folds in 12 hours (US-28C/12H), but as the temperature of storage reduced to $0^{\circ} \mathrm{C}(\mathrm{US}-0 \mathrm{C} / 12 \mathrm{H})$, rate of increase of these values remained, respectively at $1.37 \pm 0.018$, $1.35 \pm 0.016$ and $0.92 \pm 0.019$ folds only (Fig. 2).

TMAN, TVBN and AAN increased remarkably $(p<0.05)$ during the storage of $\mathrm{FBD}$ at $28^{\circ} \mathrm{C}$, but there was a considerable reduction $(p<0.05)$ in the development of TMAN, TVBN and AAN was noticed when temperature reduced to $0^{\circ} \mathrm{C}$. Trimethylamine oxidase produce by spoilage organisms reduces trimethylamine oxide of fish flesh to trimethylamine that is believed to react with fish fats to produce the typical spoilage odor that are associated with fish beyond their prime $[32,35]$. FBD samples held at $28^{\circ} \mathrm{C}$ more than 4 hours (US$0 \mathrm{C} / 8 \mathrm{H}$ and $\mathrm{US}-0 \mathrm{C} / 12 \mathrm{H}$ ) were found unacceptable by the sensory panel and scored less than 5 points on Hedonic scale. 

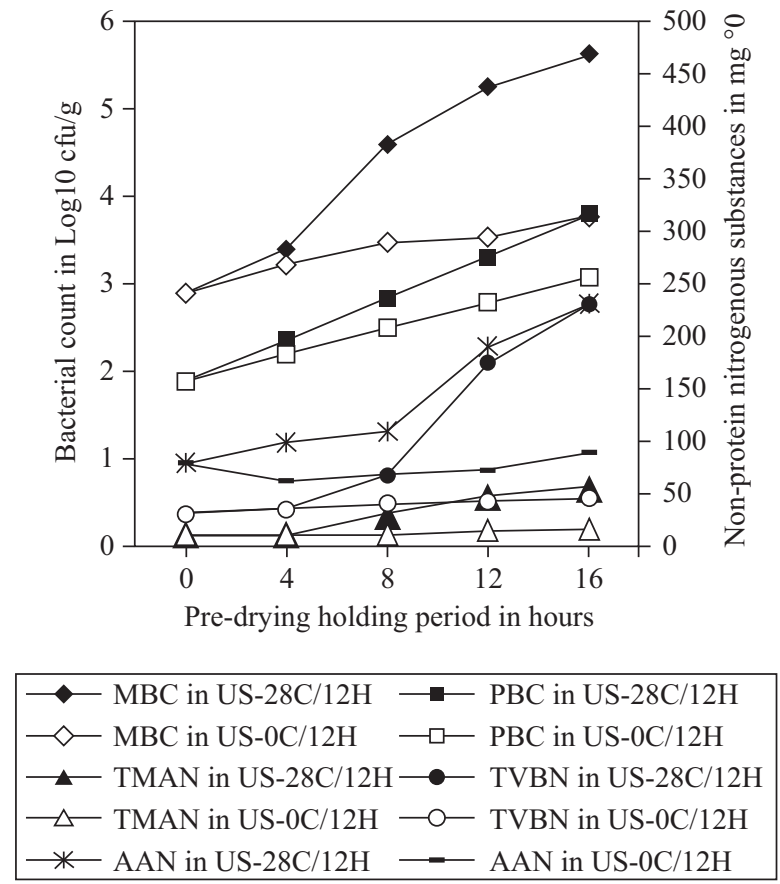

Fig. 2. Changes in $\mathrm{MBC}, \mathrm{PBC}$ and NPNs in FBD during storage at $0^{\circ} \mathrm{C}$ or $28^{\circ} \mathrm{C}$.

FFA, TMAN and TVBN registered at this point of storage were $6.76 \pm 0.02 \%$ of oleic acid, $11.83 \mathrm{mg} \%$ and $35.17 \pm 0.15$ $\mathrm{mg} \%$ respectively. The trimethylamine level in fresh fish rejected by sensory panels varies between species but is around 10 to $15 \mathrm{mg} \%$ in aerobically stored fresh fish [6] and in the present study TMAN level increased more than this level beyond 8 hours of storage at ambient temperature (US-28C/ $8 \mathrm{H}$ and $\mathrm{US}-28 \mathrm{C} / 12 \mathrm{H})$. Total volatile bases is mostly formed by bacterial or tissue autolysis leading to a deteriorative odors and flavors and its limits well be $30-35 \mathrm{mg} \%$ in teleost fishes [5], and in the present study TVBN level increased more than this level in sample stored at ambient temperature beyond 8 hours (US-28C/8H and US-28C/12H). But POV of lipids increased by $2.00 \pm 0.02$ folds of the initial values in both samples stored at 28 and $0^{\circ} \mathrm{C}$ for 12 hours (US-28C/12 and US$0 \mathrm{C} / 12$ ) (Fig. 3). It is instructive to note here that even though accumulation of fatty acids reduced drastically $(p<0.05)$ as the storage temperature of the samples reduced from 28 to $0^{\circ} \mathrm{C}$, it did not have significant effect $(p>0.05)$ on the release of peroxides. Since samples were exposed to atmospheric oxygen in both US-28C/12-FBD and US-0C/12-FBD samples, highly unsaturated fatty acids are susceptible for oxidation due to contact with oxygen [33]. Even though hydroperoxides are odorless and flavorless compounds, and not related directly to the actual sensorial objectionable rancification and discoloration as we observed in the final dried products might latter lead to objectionable secondary reactions [37].

FBD contained semitransparent body, silvery white abdomen and transparent fins, and during the exposure of the samples at the atmospheric temperature of $28^{\circ} \mathrm{C}$ turned gray-
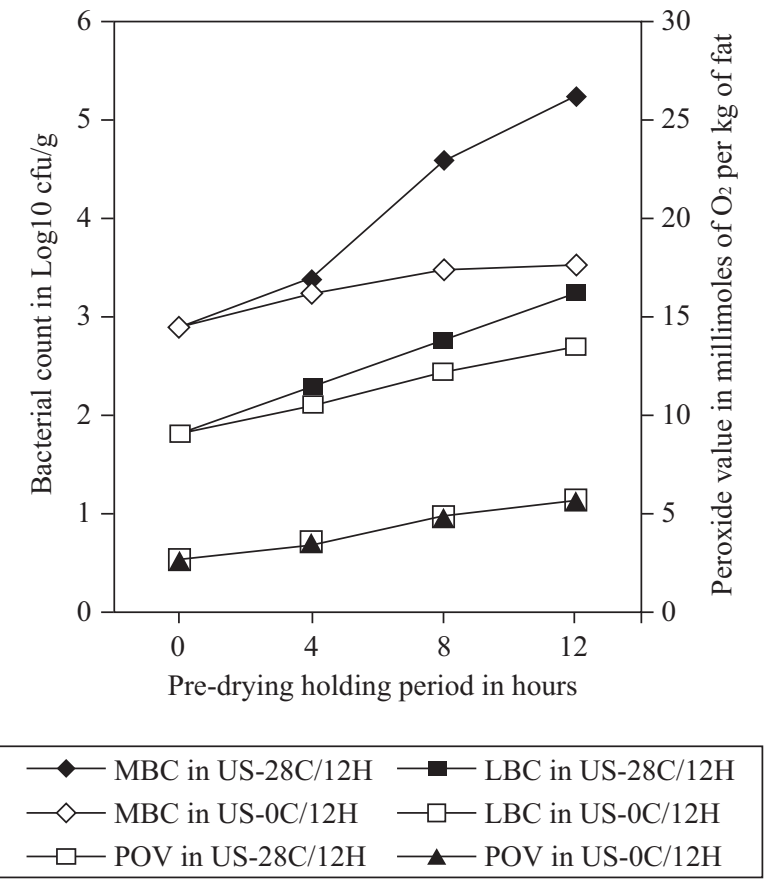

Fig. 3. Changes in $\mathrm{MBC}, \mathrm{LBC}$ and $\mathrm{POV}$ in $\mathrm{FBD}$ during storage at $0^{\circ} \mathrm{C}$ or $28^{\circ} \mathrm{C}$.

ish, translucent, and mushy by 12 hours, and was found unacceptable for human consumption by sensory panel. Since the samples were turned unfit beyond 8 hours of storage by sensory evaluation, we did not store the samples beyond 12 hours of storage. FFA, POV, TMAN, TVBN and AAN values registered at 8 hours of storage at $28^{\circ} \mathrm{C}$ was $8.19 \%$ oleic acid, 4.89 millimoles of oxygen $/ \mathrm{kg}$ of fat, $29.61 \pm 0.03 \mathrm{mg} \%$, $67.34 \pm 0.025 \mathrm{mg} \%$, and $110.15 \pm 0.02 \mathrm{mg} \%$ respectively with hedonic scale of $4.20 \pm 0.1$ points. Hence, if the huge catch of Bombay duck is waiting further processing, it is advised to chill the fish to reduce the rate of deterioration [35].

\section{Effect of Gutting and Salting on the Deteriorative Changes of Bombay Duck}

Second lot of freshly caught Bombay duck samples were degutted, washed and treated with 10, 20,36\% (Saturated) salt solution or dry salt in four different sub-lots (SA10-DBD, SA20-DBD, SA36-DBD and SADS-DBD, respectively). Since Bombay duck has a higher moisture content of $90.98 \%$ compared to other fishes, maximum period of salting in the present study was 16 hours. During pre-drying holding of DBD samples at different concentrations of salts at $28^{\circ} \mathrm{C}, \mathrm{MBC}$ increased respectively by $1.40 \pm 0.002$ and $1.28 \pm 0.003$ folds in SA10-DBD and SA20-DBD samples, but decreased respectively by $0.32 \pm 0.003$ and $0.26 \pm 0.002$ folds in SA36DBD and SADS-DBD samples. During these period PBC decreased by $0.52 \pm 0.002,0.46 \pm 0.001,0.4 \pm 0.003$, and $0.40 \pm$ 0.002 folds, and LBC decreased by $0.31 \pm 0.003,0.28 \pm 0.002$, $0.23 \pm 0.001$, and $0.20 \pm 0.002$ folds of initial value in SA10DBD, SA20-DBD, SA36-DBD and SADS-DBD samples, 


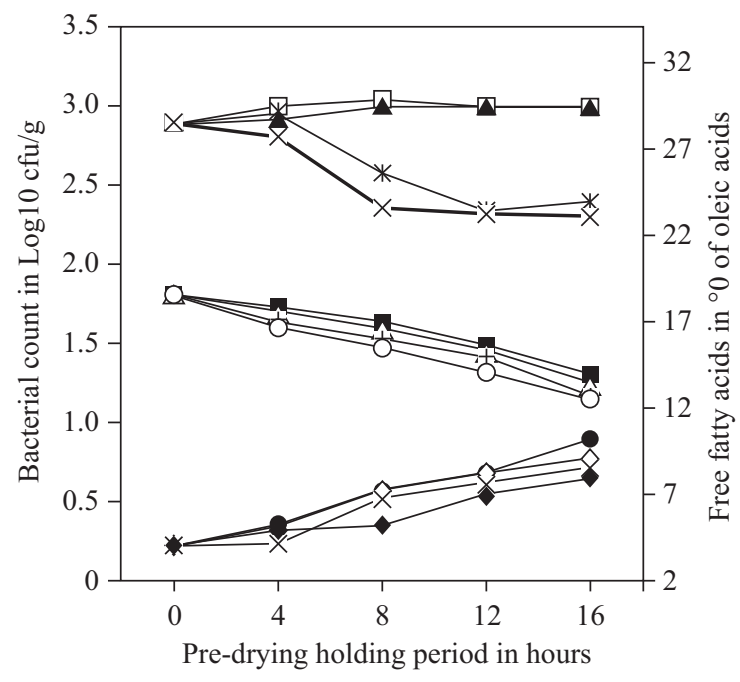

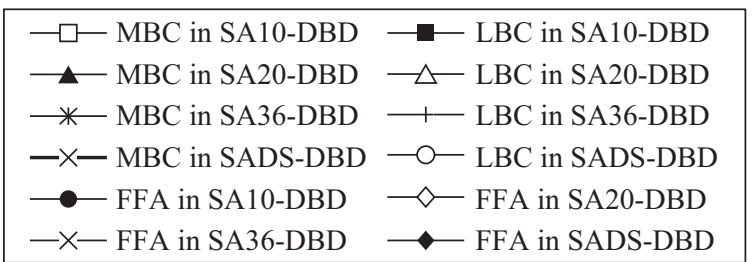

Fig. 4. Changes in MBC, LBC and FFA in SA10-DBD, SA20-DBD, SA36-DBD and SADS-DBD during salting at $28^{\circ} \mathrm{C}$.

respectively. On the other hand, FFA of samples were increased by $2.50 \pm 0.02,2.20 \pm 0.019,2.10 \pm 0.016$ and $1.90 \pm$ 0.019 folds of its initial value in samples treated with 10,20 , $36 \%$ salt solution and dry salt, respectively by 16 hours (Fig. 4).

During salting period we have observed that the rate of increase of FFA decreased $(p<0.05)$ with the increase in the concentration of salt. Similarly TMAN increased by $1.60 \pm$ $0.02,1.50 \pm 0.021,1.30 \pm 0.02$ and $1.20 \pm 0.018$ folds (Fig. 5), and TVBN increased by $1.20 \pm 0.019,1.20 \pm 0.021,1.00 \pm$ 0.021 and $1.00 \pm 0.016$ folds (Fig. 6) in samples treated with $10,20,36 \%$ salt solution and dry salt (SA10-DBD, SA20DBD, SA36-DBD and SADS-DBD, respectively), respectively by 16 hours. Even though AAN levels fluctuated during salting period increase remained at a constant rate of $1.00 \pm$ 0.012 fold (Fig. 7). TMAN and TVBN values increased ( $p<$ $0.05)$ gradually with salting period, but the rate of increase of these values decreased with the increase in salt concentration $(p<0.05)$. But it is interesting to note here that there was no significant $(p>0.05)$ difference in TMAN and TVBN values were observed in samples treated with saturated salt solution and dry salt (SA36-DBD and SADS-DBD). Similarly during salting of DBD samples, POV increased by $2.80 \pm 0.015,3.10 \pm$ $0.018,4.50 \pm 0.019$ and $4.80 \pm 0.015$ folds, respectively in SA10-DBD, SA20-DBD, SA36-DBD and SADS-DBD samples (Fig. 8). During this period contrary to FFA, rate of increase of POV increased $(p<0.05)$ with the increase in the concentration of salt, which may be due to the oxidation of highly unsaturated fatty acids in fish lipids by catalytic activity
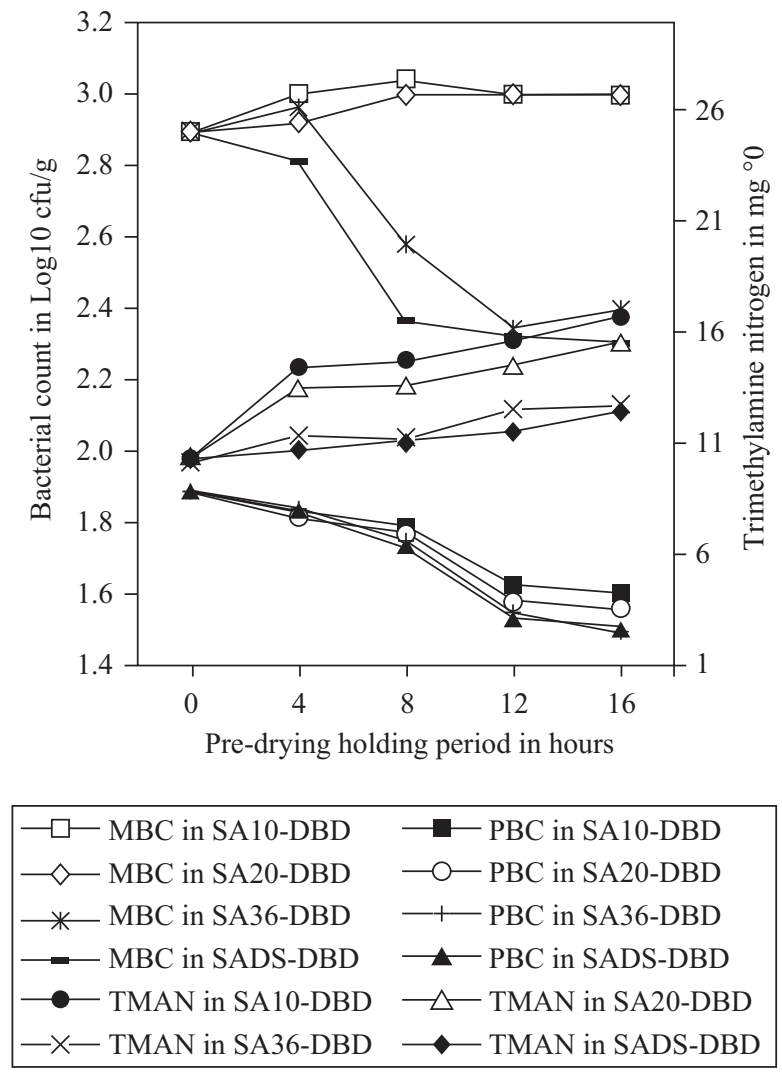

Fig. 5. Changes in MBC, $P B C$ and TMAN in SA10-DBD, SA20-DBD, SA36-DBD and SADS-DBD during salting at $28^{\circ} \mathrm{C}$.
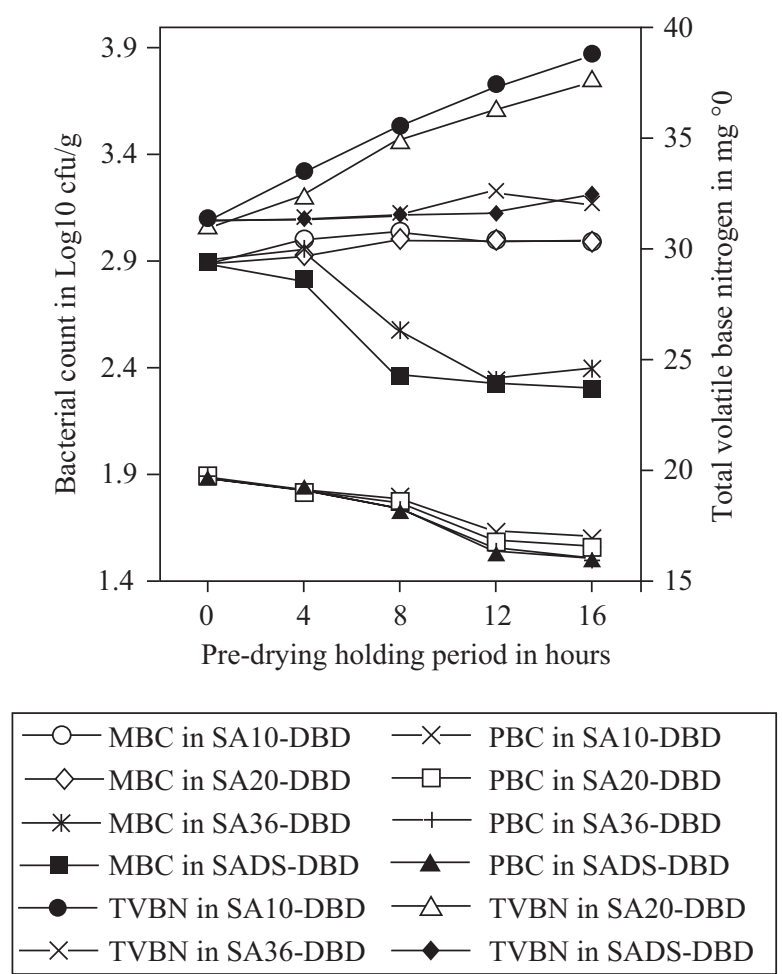

Fig. 6. Changes in MBC, PBC and TVBN in SA10-DBD, SA20-DBD, SA36-DBD and SADS-DBD during salting at $28^{\circ} \mathrm{C}$. 

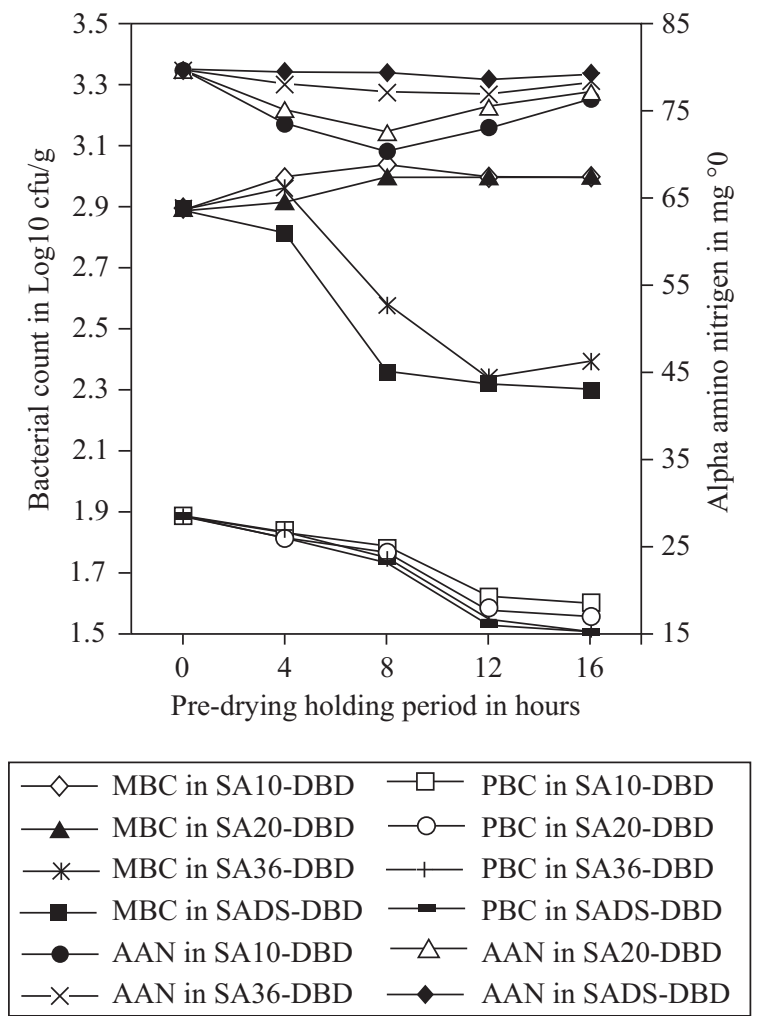

Fig. 7. Changes in MBC, $P B C$ and AAN in SA10-DBD, SA20-DBD, SA36DBD and SADS-DBD during salting at $28^{\circ} \mathrm{C}$.

of common salt, proxidation action of moisture and auto-oxidation by atmosphere oxygen [36].

At the end of the salting period moisture content was $86.19 \pm 0.035,81.29 \pm 0.04,70.56 \pm 0.03$, and $68.02 \pm 0.03 \%$ in SA10-DBD, SA20-DBD, SA36-DBD and SADS-DBD samples (Fig. 8) and salt content was $10.89 \pm 0.02,13.01 \pm 0.03$, $16.66 \pm 0.02$ and $18.02 \pm 0.02 \%$, respectively on dry weight basis. Moisture and salt content in FBD was $89.92 \pm 0.02 \%$ and $4.11 \pm 0.1 \%$, respectively. But increase in concentration of salt favors the formation of peroxides which in turn inversely correlates with the quality preference, even though washing salted Bombay duck with $3.5 \%$ salt solution prior to drying decreases salt crystal deposit over the product.

On the other hand, rate of release of fatty acids, and formation of non-protein nitrogenous substances decreased ( $p<$ 0.05 ) with the increase in the concentration of salt, may attributes to the inhibition of bacterial activity by sodium chloride [33]. Sensory panelist considered dressed Bombay duck treated with $20 \%$ salt solution for 16 hours (SA20-DBD) were best among the salted samples (SA10-DBD, SA36-DBD and SADSDBD) and scored highest for flavors (Hedonic scale of $8.6 \pm$ 1.4). Salting Bombay duck with either saturated sodium chloride solution or dry salt (SA36-DBD and SADS-DBD) was found unsuitable by sensory panelist due to the high salt content in the flesh, and samples turned opaque, faint straw color, with rough texture and longitudinal wrinkles, and samples scored $6.8 \pm 0.8$ and $6.5 \pm 1.2$ respectively on hedonic scale.
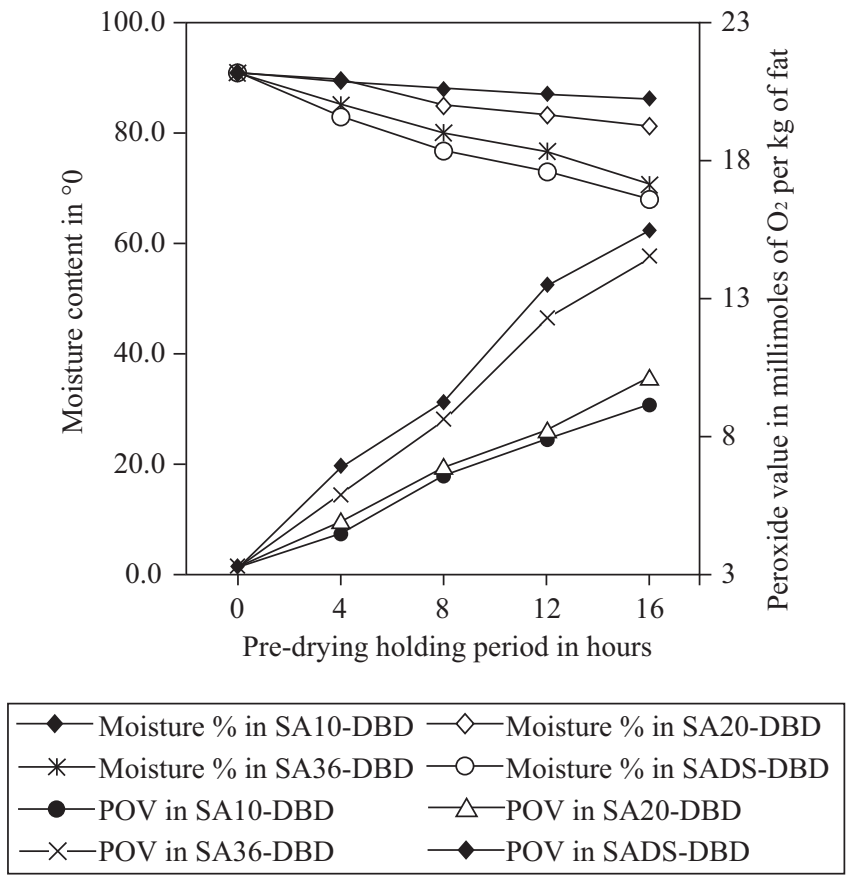

Fig. 8. Changes in Moisture content and POV in SA10-DBD, SA20-DBD, SA36-DBD and SADS-DBD during salting at $28^{\circ} \mathrm{C}$.

Samples treated with $10 \%$ sodium chloride solution were with translucent body, grayish abdomen, dark fins, and chalky surface, and samples scored $7.85 \pm 0.17$ on hedonic scale.

\section{Effect of the Artificial Drying on the Quality of the Final Dried Products}

Bombay duck samples with various pre-drying conditions (DBD, US-28C/4H, US-28C/8H, US-28C/12H, US-0C/12H, SA10-DBD, SA20-DBD, SA36-DBD and SADS-DBD), were dried artificially in Torry kiln under similar controlled conditions. At constant rate of $45^{\circ} \mathrm{C}$, with the controlled air speed of 1.003 meters per second and relative humidity of $60 \%$, it took around 40 hours to attain final moisture of $11.96 \pm 0.02 \%$ in the unsalted samples (DBD, US-28C/4H, US-28C/8H, US$28 \mathrm{C} / 12 \mathrm{H}$ or US-0C/12H), and took around 40, 36, 28 and 24 hours to attain final moisture content of $14.09 \pm 0.2,16.29 \pm$ $0.2,24.57 \pm 0.03$ and $27.36 \pm 0.02 \%$, respectively in samples treated with 10, 20,36\% salt solution, and dry salt (SA10DBD, SA20-DBD, SA36-DBD and SADS-DBD) (Fig. 9). Hence preliminary salting shortens the overall drying period to the state of sufficient dryness.

During artificial drying of DBD, US-28C/4H, US-28C/8H, US-28C/12H, US-0C/12H, SA10-DBD, SA20-DBD, SA36DBD and SADS-DBD samples, MBC increased by $79.49 \pm$ $0.65,58.67 \pm 0.95,25.00 \pm 0.72,28.33 \pm 0.45,150.00 \pm 0.95$, $272.00 \pm 0.42,100.00 \pm 0.35,4.40 \pm 0.15$ and $2.60 \pm 0.45$ folds and TMC increased by $23.13 \pm 0.45,87.88 \pm 0.23,51.43 \pm$ $0.44,44.07 \pm 0.33,138.46 \pm 0.22,33.87 \pm 0.42,11.86 \pm 0.20$, $1.20 \pm 0.09$ and $0.40 \pm 0.09$ folds from the initial value (Figs. 10 and 11). Rate of increase $(p<0.05)$ of MBC was more for 

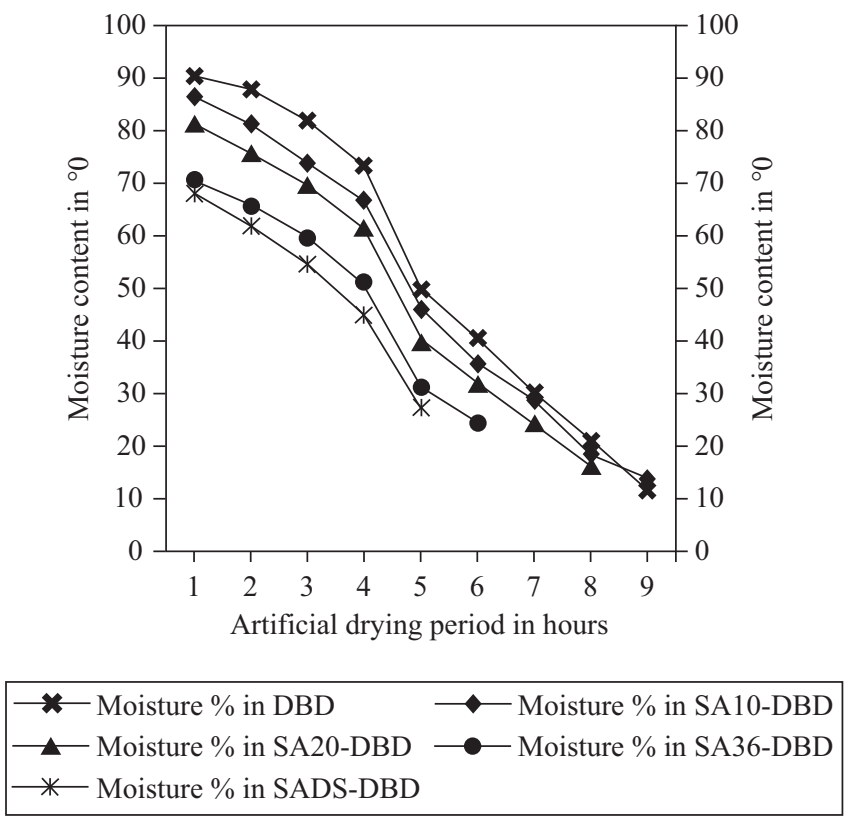

Fig. 9. Changes moisture content during artificial drying of Bombay duck with various predrying conditions.

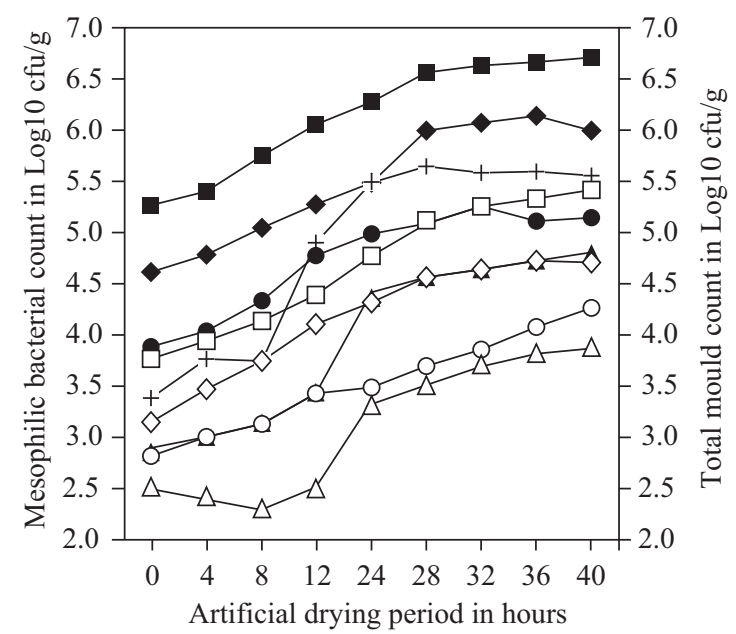

\begin{tabular}{|c|c|}
\hline$\simeq \mathrm{MBC}$ in $\mathrm{DBD}$ & $\longrightarrow \mathrm{MBC}$ in US-28C/4H \\
\hline$\longrightarrow \mathrm{MBC}$ in US-28C/8H & $\longrightarrow-\mathrm{MBC}$ in US-28C/12H \\
\hline$-+-\mathrm{MBC}$ in US-0C/12H & $\neg-\mathrm{MBC}$ in US-0C/12H \\
\hline$\triangle \mathrm{TMC}$ in $\mathrm{DBD}$ & $\multimap-\mathrm{TMC}$ in US-28C/4H \\
\hline$\diamond-\mathrm{TMC}$ in US-28C/8H & $\square \square-\mathrm{TMC}$ in US-28C/12H \\
\hline
\end{tabular}

Fig. 10. Changes $M B C$ and TMC during artificial drying of Bombay duck held at 0 or $28^{\circ} \mathrm{C}$ without salt.

SA10-DBD, followed by US-0C/12H, SA20-DBD, DBD, US-28C/12H, US-28C/8H, US-28C/4H, SA36-DBD and SADSDBD samples, however rate of increase $(p<0.05)$ of TMC was more for US-0C/12H, followed by SA10-DBD, SA20DBD, DBD, US-28C/12H, US-28C/8H, US-28C/4H, SA36DBD and SADS-DBD samples. Ii is interesting to note here that higher initial microbial load resulted in the dried fish
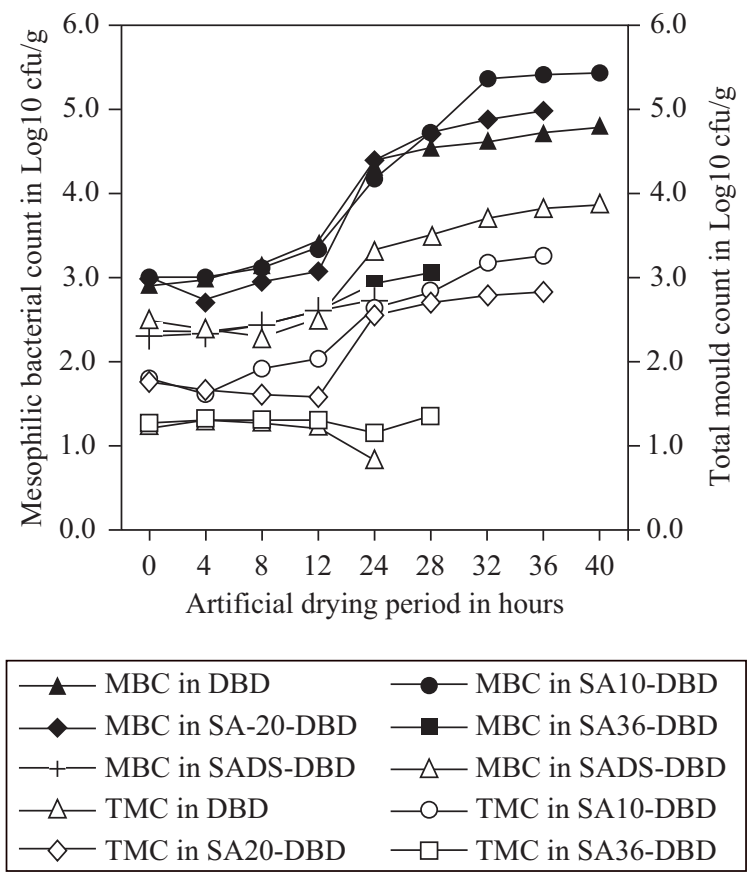

Fig. 11. Changes MBC and TMC during artificial drying of Bombay duck held at various percentages of salt.
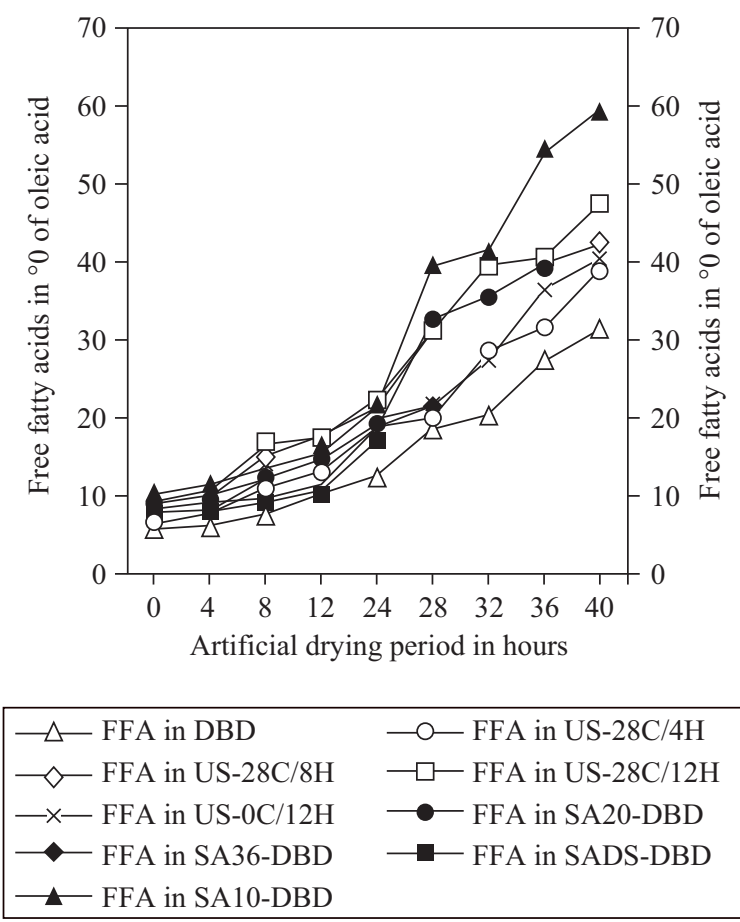

Fig. 12. Changes FFA during artificial drying of Bombay duck with various predrying conditions.

products with higher microbial load $(p<0.05)$.

FFA values of the lipids in DBD, US-28C/4H, US-28C/8H, US-28C/12, US-0C/12, SA10-DBD, SA20-DBD, SA36-DBD and SADS-DBD samples at the initial period of drying was 

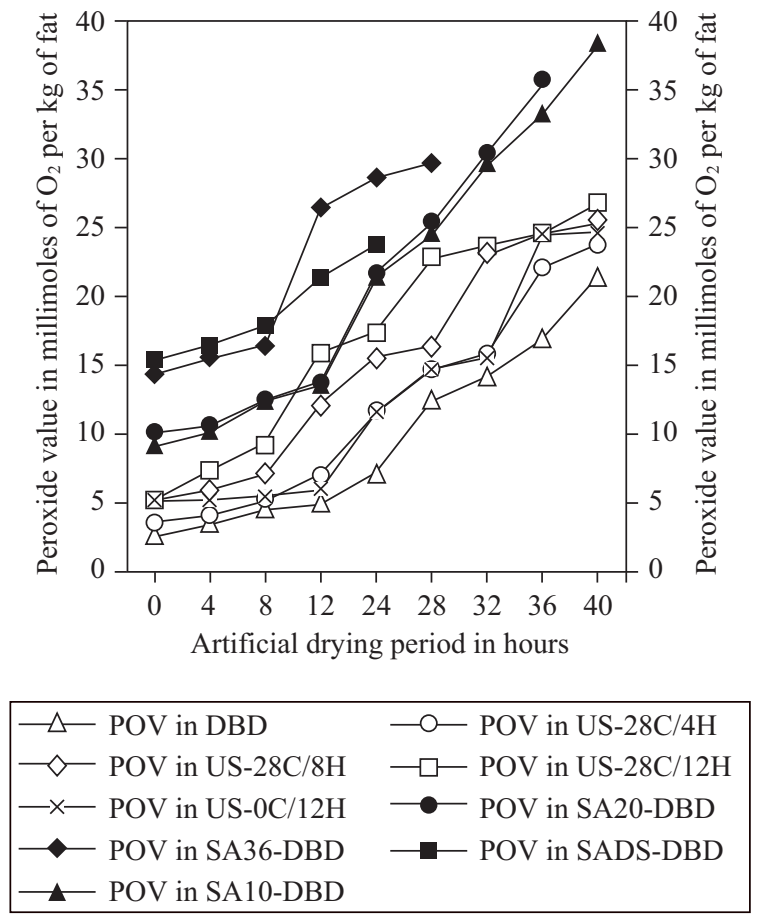

Fig. 13. Changes POV during artificial drying of Bombay duck with various predrying conditions.

$5.88 \pm 0.04,6.74 \pm 0.03,8.26 \pm 0.02,9.17 \pm 0.025,7.83 \pm 0.03$, $10.23 \pm 0.06,9.28 \pm 0.04,8.59 \pm 0.06$ and $7.87 \pm 0.03 \%$ oleic acid (Fig. 12), while POV of the lipids were $2.59 \pm 0.03$, $3.56 \pm 0.025,4.96 \pm 0.02,5.25 \pm 0.03,5.18 \pm 0.025,9.21 \pm$ $0.03,10.13 \pm 0.05,14.41 \pm 0.02$ and $15.47 \pm 0.04$ millimoles of oxygen $/ \mathrm{kg}$ of fat respectively (Fig. 13).

A POV of $10-15 \mathrm{mg} / \mathrm{kg}$ of lipids indicates rancidity [5]. During artificial drying of these samples (DBD, US-28C/4H, US-28C/8H, US-28C/12, US-0C/12, SA10-DBD, SA20-DBD, SA36-DBD and SADS-DBD), POV increased by $8.40 \pm 0.02$, $6.70 \pm 0.012,5.10 \pm 0.011,5.10 \pm 0.022,4.70 \pm 0.021,4.10 \pm$ $0.02,3.50 \pm 0.021,2.05 \pm 0.019$, and $1.50 \pm 0.016$ folds at end of respective drying period, but rate of development of FFA remained at a rate of $5.20 \pm 0.001$ folds in DBD, US-28C/4H, US-28C/8H, US-28C/12 and US-0C/12 samples, but $5.80 \pm$ $0.02,4.25 \pm 0.018,2.50 \pm 0.019$ and $1.50 \pm 0.02$ folds in SA10DBD, SA20-DBD, SA36-DBD and SADS-DBD samples. Rate of liberation of fatty acids and formation of peroxides increased $(p<0.05)$ in the same order during artificial drying of the samples held at $28^{\circ} \mathrm{C}$ or $0^{\circ} \mathrm{C}$ (US- $28 \mathrm{C} / 4 \mathrm{H}$, US- $28 \mathrm{C} / 8 \mathrm{H}$, $\mathrm{US}-28 \mathrm{C} / 12 \mathrm{H}$ or US-0C/12H). It is inferred here that the holding period at $28^{\circ} \mathrm{C}$ is related to the formation of peroxide and free fatty acids in the dried products.

Similarly, TMAN values were $10.57 \pm 0.03,11.85 \pm 0.02$, $29.44 \pm 0.03,47.51 \pm 0.02,13.96 \pm 0.025,16.82 \pm 0.02,15.52 \pm$ $0.05,12.68 \pm 0.04$ and $12.33 \pm 0.02 \mathrm{mg} \%$, TVBN values were $31.53 \pm 0.02,35.90 \pm 0.03,67.31 \pm 0.03,175.4 \pm 0.02,42.67 \pm$ $0.025,38.85 \pm 0.02,37.62 \pm 0.02,32.32 \pm 0.02$ and $32.46 \pm$ $0.02 \mathrm{mg} \%$, and AAN values were $79.44 \pm 0.02,99.32 \pm 0.025$,
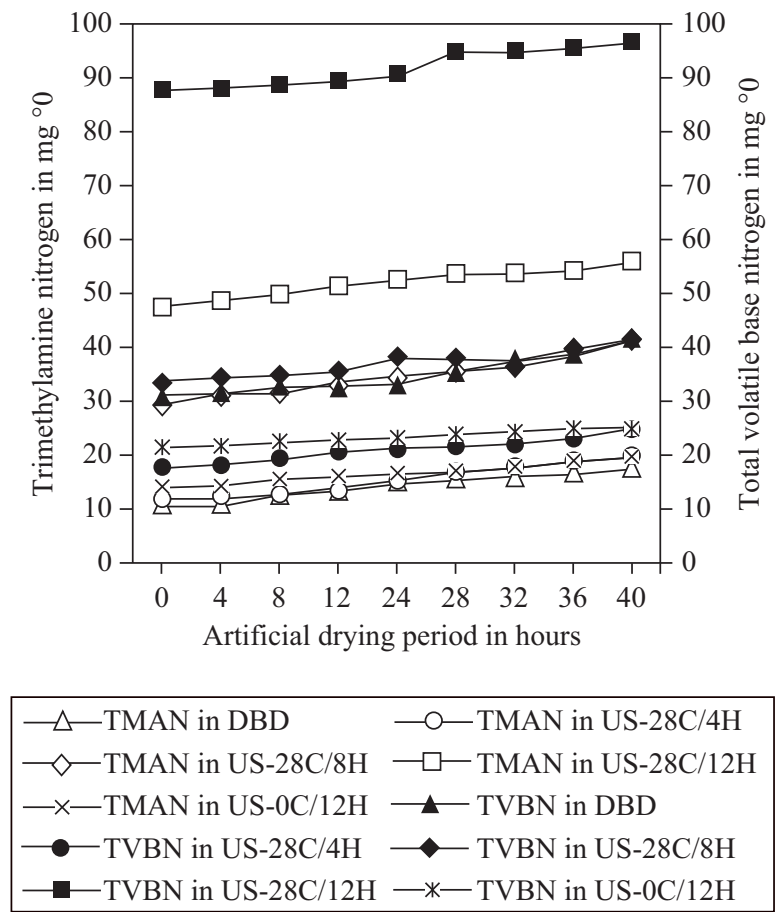

Fig. 14. Changes TMAN and TVBN during artificial drying of Bombay duck with various predrying conditions.

$110.76 \pm 0.04,189.90 \pm 0.025,72.60 \pm 0.03,76.43 \pm 0.05$, $77.17 \pm 0.12,78.66 \pm 0.09$, and $9.73 \pm 0.02 \mathrm{mg} \%$, respectively in DBD, US-28C/4H, US-28C/8H, US-28C/12, US-0C/12, SA10-DBD, SA20-DBD, SA36-DBD and SADS-DBD samples. TMAN increased by $1.7 \pm 0.02,1.7 \pm 0.01,1.40 \pm 0.03$, $1.20 \pm 0.01,1.40 \pm 0.02,1.30 \pm 0.01,1.30 \pm 0.03,1.10 \pm 0.01$ and $1.00 \pm 0.03$ folds, TVBN increased by $1.20 \pm 0.02,1.40 \pm$ $0.019,1.20 \pm 0.01,1.10 \pm 0.01,1.20 \pm 0.01,1.20 \pm 0.01$, $1.20 \pm 0.01,1.10 \pm 0.02$ and $1.00 \pm 0.009$ folds (Fig. 14), and AAN increased by $1.10 \pm 0.02,1.40 \pm 0.01,1.40 \pm 0.03,1.20 \pm$ $0.01,1.20 \pm 0.02,1.20 \pm 0.01,1.10 \pm 0.02,1.00 \pm 0.01$ and $1.00 \pm 0.02$ folds during 40 hours of artificial drying (Fig. 15). In dried fish, spoilage was quite evident, when TMAN values reached $50 \mathrm{mg} \%$ [34], but in salted fish it was still quite low, [14]. Connell [5] suggested that TVBN of $100-200 \mathrm{mg} \%$ on dry weight basis as the limit beyond which salted or dried fish could be considered as spoiled, while, Koizumi et al. [21] observed that salted dried fish could be considered as stale when TVBN increased above $100 \mathrm{mg} \%$ dry weight basis. It is found out that if the TMAN and TVBN values are higher, prior to drying, the final dried product continues to exhibit higher TMAN and TVBN values [7].

Artificial dried DBD samples were grayish white, dry fish odor, very firm with longitudinal shrinkage, and scored $7.00 \pm$ 1.4 on hedonic scale. The samples held at $28^{\circ} \mathrm{C}$ for 8 and 12 hours prior to drying (US-28C/8H, US-28C/12H) were unfit for human consumption and turned dark yellowish in color, with very strong dry-fishy smell, very firm with longitudinal shrinkage and moderately disliked by the entire panelist with 


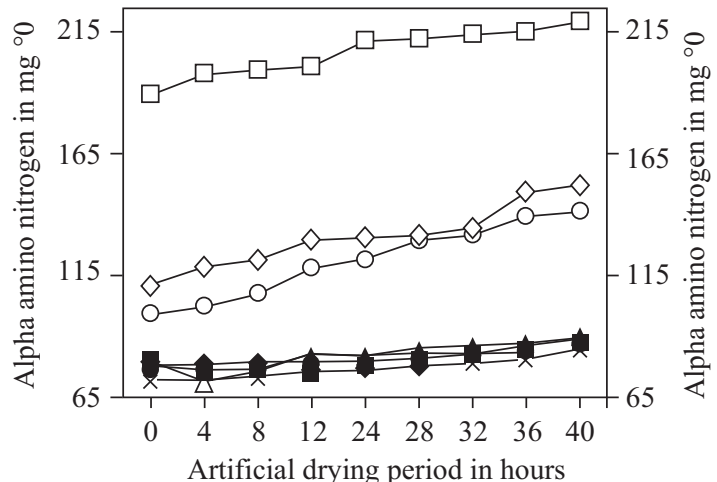

\begin{tabular}{|c|c|}
\hline & \\
\hline & \\
\hline$\prec$ AAN in US-28C/8H & $\square \square$ AAN in US-28C/12H \\
\hline$-x-\mathrm{AAN}$ in US-0C/12H & $\smile$ AAN in SA10-DBD \\
\hline$\longrightarrow$ AAN in SA20-DBD & $\longrightarrow$ AAN in SA36-DBD \\
\hline$\longrightarrow$ AAN in SADS-DBD & \\
\hline
\end{tabular}

Fig. 15. Changes AAN during artificial drying of Bombay duck with various predrying conditions.

the Hedonic scale of $3.23 \pm 0.15$ and $3.02 \pm 0.13$, respectively.

While samples held at $0^{\circ} \mathrm{C}$ for 12 hours (US-0C/12H) were turned straw yellow color, with slight dry-fishy colors, very firm with longitudinal shrinkage and scored $6.60 \pm 1.5$ and those samples held at $28^{\circ} \mathrm{C}$ for 4 hours (US-28C/4H) were turned straw yellow color, with slight dry-fishy odour, very firm with longitudinal shrinkage and scored $6.00 \pm 1.5$, during 40 hours of artificial drying. While comparing salted and artificial dried samples, artificial dried sample treated with $20 \%$ salt (SA20-28C/16H) was rated best (Hedonic score of $8.20 \pm 1.4$ ) with the better appealing color of grayish white and firm texture. In general terms DBD samples scored 7.00 \pm 1.4 , SA10-DBD samples scored $7.60 \pm 1.6$, SA20-DBD samples $8.20 \pm 1.4$, SA36-DBD samples scored $6.60 \pm 0.09$ and SADSDBD samples scored $6.20 \pm 1.2$ on hedonic scale. It is interesting to note here that as the salt concentration increased, colour of the samples turned from grayish white to increasing yellowish ting with salt deposits on the surface, but became softer and smoother. In fact direct comparison between salted samples may not hold true as the moisture levels varied between $11.96 \pm 0.02$ and $27.36 \pm 0.02 \%$ amongst the samples. Hence the initial quality of the Bombay duck fish has a direct impact on the quality of final dried products. Through the use of salt over all drying period can be reduced and can have better soft texture. If the salt is not used, the final product is needed to dry at moisture content around $15 \%$ for better storage life and if salt is used, the higher moisture levels can be used.

\section{CONCLUSION}

Freshly caught Bombay duck becomes unfit for human consumption beyond 8 hours of holding at ambient tempera- ture as decided by the microbial, biochemical and sensory characteristics. If Bombay duck caught are waiting for further processing it is advisable to chill them just above the freezing point to retard the spoilage, as indicated by lower MBC, PBC, LBC, FFA, TMAN, TVBN and AAN. However, this is inefficient in preventing the accumulation of peroxides. On the other hand, gutting and salting the freshly caught Bombay duct prior to artificial drying reduces the drying period and reduces the deteriorative changes. Even though increase in the concentration of salt decreases deteriorative changes as indicated by higher microbial count and non-protein nitrogenous substances in Bombay duck, higher concentration of salt facilitates the peroxide accumulation and decreases the quality preference due to discoloration and salt deposits. The initial quality of the raw material used and spoilage taking place during drying has a direct impact on the quality of the final dried product. At the end of drying period dressed Bombay duck, treated with $20 \%$ salt solution for 16 hours and artificially dried at $45^{\circ} \mathrm{C}$ was judged superior by sensory panel.

\section{REFERENCES}

1. Aidos, I., Schelvis-Smit, R., Veldman, M., Luten, J. B., Van Der Padt, A., and Boom, R. M., "Chemical and sensory evaluation of crude oil extracted from herring byproducts from different processing operations," Journal of Agricultural and Food Chemistry, Vol. 51, No. 7, pp. $1897-$ 1903 (2003).

2. APHA, Recommended Procedure for the Examination of Seawater and Shellfish, $2^{\text {nd }}$ ed., American Public Health Association, Washington, pp. 12-13 (1982).

3. Ashie, I. N., Smith, J. P., and Simpson, B. K., "Spoilage and shelf-life extension of fresh fish and shellfish," Critical Reviews in Food Science and Nutrition, Vol. 36, No. 1-2, pp. 87-121 (1996).

4. Collins, C. H., Microbial Methods, $2^{\text {nd }}$ ed., Butterworth, London, p. 63 (1967).

5. Connell, J. J., "Control of fish quality," Fishing News (Book) Ltd., London, pp. 107-132 (1980).

6. Dalgaard, P., Gram, L., and Huss, H. H., "Spoilage and shelf life of cod fillets packed in vacuum or modified atmospheres," International Journal of Food Microbiology, Vol. 19, pp. 283-294 (1993).

7. Dissaraphong, S., Benjakul, S., Visessanguan, W., and Kishimura, H., "The influence of storage conditions of tuna viscera before fermentation on the chemical, physical and microbiological changes in fish sauce during fermentation," Bioresource Technology, Vol. 97, No. 16, pp. 2032 2040 (2006).

8. FAO, "The prevention of losses in cured fish," Fisheries Technical Paper, FAO, Rome, Vol. 219, pp. 87-88 (1981).

9. FAO, "Support to regional aquaculture activities in Latin America and the Caribbean,” In: Olvera-Novoa, M. A., Martinez Palacios, C. A., and Real de Leon, E. (Eds.), Nutrition of Fish and Crustaceans- a Laboratory Manual, AB479/E, Food and Agriculture Organization of the United Nations, FAO, Mexico City, pp. 61-62 (1994).

10. Gray, J. I., Pearson, M. A., and Monahan, F. J., "Flavor and aroma problems and their measurement in meat, poultry and fish product," In: Pearson, A. M. and Dutson, T. R. (Eds.), Quality Attributes and Their Measurement in Meat, Poultry and Fish Products-Advance in Meat Research, Blackie Academic and Professional, London, pp. 250-278 (1994).

11. Gupta, R. and Samuel, C. T., "Some fungal infestations of dried fishes in Cochin market," Fishery Technology, Vol. 22, No. 5, pp. 132-134 (1985).

12. Hardy, R., "Fish lipids. Part. 2," In: Connell, J. J. (Ed.), Advance in Fish 
Science and Technology, Fishing News (Books) Ltd., London, pp. 103114 (1980).

13. Hsuich, R. J. and Kingsella, J. E., "Lipoxygenase catalysed oxidation of N-6 and N-3 Poly unsaturated fatty acids: Relevance to and activity in fish tissue," Journal of Food Science, Vol. 51, No. 4, pp. 940-946 (1986).

14. Ishida, Y., Fujii, T., and Kadota, H., "Microbial studies on salted fish stored at low temperature. I. Chemical changes of salted fish during storage," Bulletin of the Japanese Society for the Science of Fish, Vol. 42, No. 3, pp. 351-358 (1976).

15. IS: 5734, "Indian standard specifications for sardine oil," Bureau of Indian Standards, New Delhi, pp. 6-7 (1970).

16. IS: 5736, "Indian standard specifications for sardine oil-(Tuna)," Bureau of Indian Standards, New Delhi, pp. 1-4 (1985).

17. IS: 8836 , "Indian standard specifications for dry salted doma," Bureau of Indian Standards, New Delhi, pp. 1-4 (1985).

18. Joseph, K. G., Muraleedharan, V., and Nair, T. S. U., "Quality of cured fishery products from Malabar and Kanara coast," Fishery Technology, Vol. 20, No. 2, pp. 118-122 (1983).

19. Joseph, K. G., Muraleedharan, V., Nair T. S. U., and Kalaimani, N., "Quality of cured fish from the Maharashtra coast," Fishery Technology, Vol. 23, No. 1, pp. 63-69 (1988).

20. Kaneniwa, M., Yokoyama, M., Murata, Y., and Kuwahara, R., "Enzymatic hydrolysis of lipids in muscle of fish and shellfish during cold storage," Advances in Experimental Medicine and Biology, Vol. 542, pp. 113-119 (2004).

21. Koizumi, C., Oshima, T., and Wada, S., "Preservative effect of sodium chloride in salted and dried fish products," Bulletin of the Japanese Society for the Science of Fish, Vol. 51, No. 1, pp. 87-90 (1985).

22. Larmond, E., "Laboratory methods for sensory evaluation of foods," Research Branch, Canadian Department of Agriculture Publication, pp. 56-59 (1977)

23. Leo, R. D., "Methods in Food and Dairy Microbiology," In: Leo, R. D. (Ed.), A Laboratory Training Manual for Quality Control Test, AVI Publishing Company Inc., Westport, pp. 35-36 (1982).

24. Lima Dos Santos, C. M. M., James, D., and Teutscher, F., "Guidelines for chilled fish storage experiments," FAO, Fisheries Technical Paper, Vol. 210, pp. 17-19 (1981).

25. Martin, P. G., "Manual of food quality. 3. Commodities," FAO Food and Nutrition Paper, Food and Agriculture Organization of the United Nations, FAO, Rome, Vol. 14, No. 3, pp. 175-178 (1979).

26. Mutsumoto, J. J., "Denaturation of fish muscle proteins during frozen storage," In: FENNEMA, O. (Ed.), Proteins at Low Temperature, Ad- vances in Chemical Series, No. 180, American Chemical Society, Washington, pp. 12-68 (1979).

27. Nooralabettu, K. P., "Effect of sun drying and artificial drying of fresh, salted Bombay duck (Harpodon neherius) on the physical characteristics of the product," Journal of Aquatic Food Product Technology, Vol. 17, No. 2, pp. 99-116 (2008).

28. Ola, J. B. and Oladipo, A. E., "Storage life of croaker (Pseudotholitus senegalensis) in ice and ambient temperature," African Journal of Biomedical Research, Vol. 7, No. 1, pp. 13-17 (2004).

29. Pope, C. G. and Stevens, M. F., "The Determination of amino nitrogen using copper method," Biochemical Journal, pp. 1070-1071 (1939).

30. Regenstein, M. J. and Regenstein, C. E., "Introduction to fish technology,” In: Regenstein, M. J. and Regenstein, C. E. (Eds.), Shelf Life Considerations for Fresh Fish, An Osprey Book, Van Nostrand Reinhold, New York, pp. 63-89 (1991).

31. Shahidi, F. and Botta, J. R., Seafoods: Chemistry, Processing Technology and Quality, Chapman \& Hall, London, pp. 3-9 (1994).

32. Sikorski, Z. E., Kolakowska, A., and James, R. B., "Post harvest biochemical and microbiological changes," In: Seafood resources, nutritional composition and preservation, (Z. E. SIKORSKI, Ed.), CRC Press, Boca Raton, Florida, pp. 93-109 (1990).

33. Sikorski, Z. E. and Pan, S. N., "Preservation of seafood quality," In: Shahidi, F. and Botta, J. R. (Eds.), Seafoods: Chemistry, Processing Technology and Quality, Blackie Academic and Professional, London, pp. 168-195 (1994).

34. Spineli, J. and Dassow, A. J., "Fish Proteins: Their modification and potential uses in food industry," In: Martin, E. R., Flick, J. G., Hebard, E. C., and Ward, R. D. (Eds.), Chemistry and Biochemistry of Marine Food Products, AVI Publishing Company, West Port, Connecticut, pp. 13-23 (1982).

35. Triqui, R. and Bouchriti, N., "Freshness assessments of Moroccan sardine (Sardina pilchardus): comparison of overall sensory changes to instrumentally determined volatiles," Journal of Agricultural and Food Chemistry, Vol. 51, No. 26, pp. 7540-7546 (2003).

36. Wheaton, F. M. and Lawson, J. B., Processing of Aquatic Food Products, John Weiley and Sons, New York, pp. 181-329 (1985).

37. Zhao, Q., Xue, C., Xu, J., Sheng, W., Xue, Y., and Li, Z., "Analysis of volatile compounds in bighead carp by microwave, distillation and solid phase microextraction coupled with gas chromatography-mass spectrometry and olfactometry," Chinese Journal of Chromatography/Zhongguo Hиа Хие Hui, Vol. 25, No. 2, pp. 267-271 (2007). 